\title{
Effect of hydrogen cyanamide on the endogenous hormonal content of pea seedlings (Pisum sativum L.)
}

\author{
Eric Guevara ${ }^{1}$, Víctor M. Jiménez ${ }^{1 *}$, Jorge Herrera ${ }^{1}$ and Fritz Bangerth ${ }^{2}$
}

${ }^{1}$ CIGRAS, Universidad de Costa Rica, 2060 San Pedro, Costa Rica. ${ }^{2}$ Institute for Special Crop Cultivation and Crop Physiology (370), University of Hohenheim, D 70593, Stuttgart, Germany. *Corresponding author: victor.jimenez@ucr.ac.cr

Received: 15 May 2008; Returned for revision: 23 June 2008; Accepted: 01 July 2008

Hydrogen cyanamide (HC) has been used to break bud and seed dormancy and to improve rooting in several species, responses usually associated with the action of plant hormones. However, very few studies have measured endogenous hormones after HC treatment. Therefore, pea (Pisum sativum L.) seedlings with two fully developed internodes above the first leaf were sprayed with $0,0.1$ and $0.3 \%$ (v/v) HC. Endogenous concentration of indole-3-acetic acid (IAA), abscisic acid (ABA), zeatin/zeatin riboside and $N^{6}\left(\Delta^{2}\right.$-isopentenyl) adenine/ $N^{6}\left(\Delta^{2}\right.$-isopentenyl) adenosine were measured by radioimmunoassay 31 and $80 \mathrm{~h}$ after HC treatment. A significant increase in ABA and cytokinin (CK) levels was observed $31 \mathrm{~h}$ after treating the plants with $0.3 \% \mathrm{HC}$. Small necrotic spots were also noticed in this treatment, thus revealing a toxic effect of this treatment. Additionally, at $80 \mathrm{~h}$, a significant increase in IAA was found for both HC concentrations applied. The action of HC upon ABA, CKs and IAA endogenous levels is discussed.

Key words: abscisic acid, cytokinins, indole-3-acetic acid

Efeito da cianamida hidrogenada sobre o conteúdo de hormônios endógenos em plântulas de ervilha (Pisum sativum L.): A cianamida hidrogenada $(\mathrm{CH})$ tem sido usada para quebrar a dormência de sementes e estimular o enraizamento em várias espécies, respostas estas usualmente associadas com a ação de hormônios de plantas. Todavia, em muito poucos estudos se tem avaliado os níveis endógenos de hormônios após a aplicação de CH. Portanto, plântulas de ervilha (Pisum sativum L.), com dois internódios completamente desenvolvidos acima da primeira folha, foram pulverizadas com soluções de CH a 0; 0,1; e 0,3\% (v/v). Concentrações endógenas de ácido indol-3-acético (AIA), ácido abscísico (AAB), zeatina/ribosídeo de zeatina e $N^{6}\left(\Delta^{2}\right.$-isopentenil) adenina/ $N^{6}\left(\Delta^{2}\right.$-isopentenil) adenosina foram medidas por radioimunoensaio após 31 e 80 h da aplicação de $\mathrm{CH}$. Observaram-se aumentos significativos nas concentrações de AAB e citocininas 31 h após o tratamento das plantas com 0,3\% de $\mathrm{CH}$. Verificaram-se pequenas manchas necróticas nas plantas desse tratamento, que se revelou, pois, tóxico. Adicionalmente, observou-se um incremento na concentração de AIA após 80 h da aplicação de $\mathrm{CH}$, tanto a 0,1 como a 0,3\%. Discute-se a ação da $\mathrm{CH}$ sobre as concentrações endógenas de AAB, AIA e citocininas.

Palavras-chave: ácido abscísico, ácido indol-3-acético, citocininas

Hydrogen cyanamide (HC) is widely used for breaking bud dormancy in several deciduous fruit crops in regions with insufficient low temperatures during winter time. This compound is commonly applied to fruit species such as grapevine, kiwi, apple, peach and other stone fruits (Mahhou et al., 2003; Pérez and Lira, 2005). Hydrogen cyanamide has also been effective in breaking dormancy in seeds of peanut (Alizaga et al., 1992) and oil palm (Herrera et al., 1998), and in potato tubers (Northcott and Nowak, 1988; Guevara and Herrera, 1989). Other HC responses suggest involvement of endogenous plant hormones in the reaction to this compound. For example, the seedlings developed 
from oil palm and peanut dormant seeds treated with HC to induce germination show strong root development, as compared to the control treatment and to the application of a cytokinin (CK) (Alizaga et al., 1992; Herrera et al., 1998). Moreover, it has been observed that HC stimulates growth and development of roots in cuttings of several species (Guevara and Jiménez, unpublished results), which may suggest interaction with auxins.

Supporting the hypothesis that HC acts, at least partially, by inducing changes in concentrations of endogenous hormones, Northcott and Nowak (1988) observed an initial reduction in polyamine concentration in HC-treated potato tubers, which increased when tubers started to sprout. Additionally, Lombard et al. (2006) measured an increase in the zeatin riboside ( $Z R$ ) concentration after treating grape plants with HC. However, a general overview could not be gained from those studies because only one hormone group was analyzed in each case. Very recently, we found that treatment of oil palm seeds with HC mainly caused an increase in the IAA concentrations in embryos and endosperm during the imbibition phase (Jiménez et al., 2008). In this latter work, ABA, gibberellins $\mathrm{GA}_{1}, \mathrm{GA}_{3}$ and $\mathrm{GA}_{20}$, and CKs were also measured. However, no study has been conducted to simultaneously analyze changes in endogenous levels of several plant hormones following $\mathrm{HC}$ application directly to plants. Since pea has been used as a "model plant" in many studies on hormonal regulation of several physiological processes, such as apical dominance and leaf development (Demason and Chawla, 2006; Wang et al., 2006; and references therein), this species was chosen to conduct the experiment described below.

Pea seeds (Pisum sativum L. cv. Lisa) were surfacesterilized with sodium hypochlorite $(1 \%$, w/v) for 5 min and then washed three times with distilled water. They were subsequently imbibed in small trays containing enough water to slightly cover the seeds. After $2 \mathrm{~d}$, seeds with a visible radicle were planted in trays containing wet vermiculite and grown at $25^{\circ} \mathrm{C}$ with a $16 \mathrm{~h}$ photoperiod provided by $400 \mathrm{~W}$ HQI lamps (Osram, Munich, Germany), which gave a photon flux density of approximately $500 \mu \mathrm{mol}$ $\mathrm{m}^{-2} \mathrm{~s}^{-1}$. The level of water was checked daily and the plants were watered when necessary. Eight days later, when the first unifoliate leaf above the cotyledons was visible, plants were fertilized at the base of $2 \mathrm{~mL} \mathrm{~L}^{-1}$ of Wuxal complete nutrient solution (Aglukon GmbH, Düsseldorf, Germany).
Ten days later, when at least two fully developed internodes above the first leaf were formed, plants were divided in three homogenous groups, each treated with one of the following HC concentrations: $0,0.1$ and $0.3 \% \mathrm{v} / \mathrm{v}$ of active ingredient (Dormex, 49\% HC, SKW, Trostberg, Germany) containing one drop of Tween 20 per $100 \mathrm{~mL}$ solution. The treatments were sprayed on the aerial part of the plants with a manual sprayer, ensuring complete coverage of the plant surface.

Samples were collected 31 and $80 \mathrm{~h}$ after treating the plants with HC. Each sample comprised the aerial part (including leaves) of 15 plants (cut above the vermiculite level). Samples were immediately frozen in liquid nitrogen and stored at $-20^{\circ} \mathrm{C}$ until further processing. Three samples were collected for each treatment and sampling date.

For extraction of IAA, ABA, zeatin (Z) /ZR, and $N^{6}\left(\Delta^{2}-\right.$ isopentenyl) adenine/ $N^{6}\left(\Delta^{2}\right.$-isopentenyl) adenosine (iP/ iPA), $1.5 \mathrm{~g}$ of the frozen samples were ground in liquid nitrogen and then homogenized with $100 \mathrm{~mL} \mathrm{80 \%} \mathrm{(v/v)}$ methanol with an Ultra Turrax (Janke and Kunkel, Staufen, Germany) and incubated overnight at $4^{\circ} \mathrm{C}$. Purification and determination of the above-mentioned hormones were performed as described by Jiménez et al. (2005). Briefly, the extract was filtered through G4-glassinterfilters (max. pore size 10-16 $\mu \mathrm{m}$; Schott, Mainz, Germany), then dried under low pressure and dissolved in $12 \mathrm{~mL} 0.1 \mathrm{M}$ ammonium acetate ( $\mathrm{pH}$ 9.0) by using an ultrasonic bath and subsequently frozen at $20^{\circ} \mathrm{C}$ overnight. After thawing, the extract was centrifuged at $4^{\circ} \mathrm{C}$ for $25 \mathrm{~min}$ at $22000 \mathrm{~g}$ to remove macromolecular substances like lipids, proteins, etc. For further purification, the supernatant from the centrifugation step was passed through a preconditioned column combination, assembled in the following sequence: PVP (Sigma, Deisenhofen, Germany); DEAE Sephadex A-25 (Pharmacia, Freiburg, Germany); $\mathrm{C}_{18}$ Sep-Pak cartridge (Waters, Eschborn, Germany). The extracts were first loaded onto the syringe filled with PVP and eluted with $30 \mathrm{~mL} 0.01$ $\mathrm{M}$ ammonium acetate ( $\mathrm{pH}$ 7.5). At this point, the acidic hormones (IAA, ABA) were bound as anions to the DEAE Sephadex, while the CKs passed through to the Sep-Pak cartridge. This cartridge was then replaced by a second one preconditioned for ABA. The PVP column retaining the phenolic substances and other impurities was discarded, and ABA eluted from the DEAE Sephadex into the second cartridge with $15 \mathrm{~mL} 0.75 \mathrm{M}$ ammonium acetate. Finally the second cartridge was replaced by a third one preconditioned for IAA, which was then eluted from the 
Sephadex into this cartridge with $10 \mathrm{~mL} 2.0 \mathrm{M}$ ammonium acetate. Thereafter the cartridge containing the CKs was washed with $4 \mathrm{~mL} 0.01 \mathrm{M}$ ammonium acetate and the cartridges with the acidic hormones with $4 \mathrm{~mL} 0.1 \mathrm{M}$ acetic acid. All hormones were then eluted from the cartridges with $4 \mathrm{~mL}$ of the following solutions: $30 \%$ methanol for Z/ZR; 80\% methanol for iP/iPA; $40 \%$ methanol in $0.1 \mathrm{M}$ acetic acid for IAA and 65\% methanol in $0.1 \mathrm{M}$ acetic acid for ABA. Using this procedure, inactive and conjugated forms of IAA, ABA and CKs were removed from the assay and, therefore, did not interfere with the measurement of the active and free forms in the following step. Hormones were quantified by radio-immunoassay using polyclonal antibodies.

Overall recovery during the described purification procedures was determined in parallel samples after overnight extraction with radiolabelled internal standards, and ranged between 40 and $70 \%$ for IAA, over $90 \%$ for ABA and close to $80 \%$ for both CKs. Due to the high variation found in IAA recovery values, an internal IAA standard of $1\left[{ }^{14} \mathrm{C}\right]$-IAA (specific activity $518 \mathrm{GBq}$ mol $^{-1}$; Amersham, Braunschweig, Germany) was included in each one of the samples, and the IAA concentration results were adjusted accordingly. The other hormones were not corrected for losses.

Endogenous hormonal levels were analyzed using three biological replications and statistical analysis was carried out using Infostat (Universidad Nacional de Córdoba, Argentina). The LSD-Fisher Test was used to determine significant differences between means $(P<0.05)$.

Thirty-one hours after applying the spray treatments, small chlorotic spots (2-3 mm in diameter) were observed on the leaves of plants treated with the higher $(0.3 \%) \mathrm{HC}$ concentration tested. These spots turned dark brown and later became necrotic. This suggests toxic effects of HC at that concentration. Leaf and bud necrosis has already been reported in vegetative aerial parts of Psidium guajava (Quijada et al., 1999) and Citrus latifolia (Cañizares and Rojas, 2001) plants sprayed with 0.5\% HC. Actively-growing leaves are, therefore, presumably more sensitive than buds and seeds to low concentrations of $\mathrm{HC}$, a product that is normally used in doses of $2 \%$ or above for dormant tissues. Pérez and Lira (2005) observed a reduced catalase activity in dormant buds of grapevine treated with $\mathrm{HC}$, followed by an increase in the $\mathrm{H}_{2} \mathrm{O}_{2}$ levels in the buds. It is known that accumulation of reactive oxygen species (ROS), such as $\mathrm{H}_{2} \mathrm{O}_{2}$, may cause lipid oxidation and, as a result, necrosis of the tissues (Apel and Hirt, 2004). Although a direct toxic effect of Tween 80, a related surfactant to the one used in this experiment, has been reported in other species (Thimmaraju et al., 2003), the absence of damage at the lower HC concentration and control plants, points to toxicity by $\mathrm{HC}$ instead.

Indole-3-acetic acid was the only hormone whose endogenous concentration responded to lower HC concentration (Figure 1A). No significant differences between treatments were detected in the IAA levels $31 \mathrm{~h}$ after HC application. However, $80 \mathrm{~h}$ after treating the plants, the IAA levels measured in control plants decreased significantly, while those in both HC treatments increased. This may indicate that IAA, possibly together with $\mathrm{H}_{2} \mathrm{O}_{2}$, was among the initial reactions of the plant to the $\mathrm{HC}$ treatment, even at low concentrations of this product. This increase in IAA could be a response to stress, such as the one mentioned above, as pointed out by Quirino et al. (1999) for Arabidopsis thaliana and by Havlová et al. (2008) in tobacco. This IAA upsurge might trigger other hormonal changes. For example, it has been recently demonstrated by kinetic and molecular studies that auxin herbicides and IAA by itself can initiate a "reaction chain" that starts with an increase in IAA, or related auxins, which induces ethylene biosynthesis, which in turn accelerates ABA biosynthesis and possibly jasmonic acid production (Grossman, 2007; and references therein).

At $0.3 \%$ concentration, HC caused a significant increase in endogenous ABA already after $31 \mathrm{~h}$. Those levels were approximately three times higher in this treatment than in the control and the lower HC concentration (Figure 1B). Increased ABA concentration was also maintained after $80 \mathrm{~h}$. The rise in $\mathrm{ABA}$ as a result of the higher HC dose may be more a consequence of stress [as reviewed by Netting (2000)] than a direct stimulation of ABA synthesis by HC. In the latter case an increase in ABA should have also been observed with the lower HC concentration.

Both CKs evaluated behaved similarly to each other. Thirty-one h after treatment, CK concentrations were twice as high in $0.3 \%$ HC-treated plants compared to $0.1 \%$ $\mathrm{HC}$ and control. After $80 \mathrm{~h}$, the plants treated with the lower HC concentration also showed an increase in CKs 

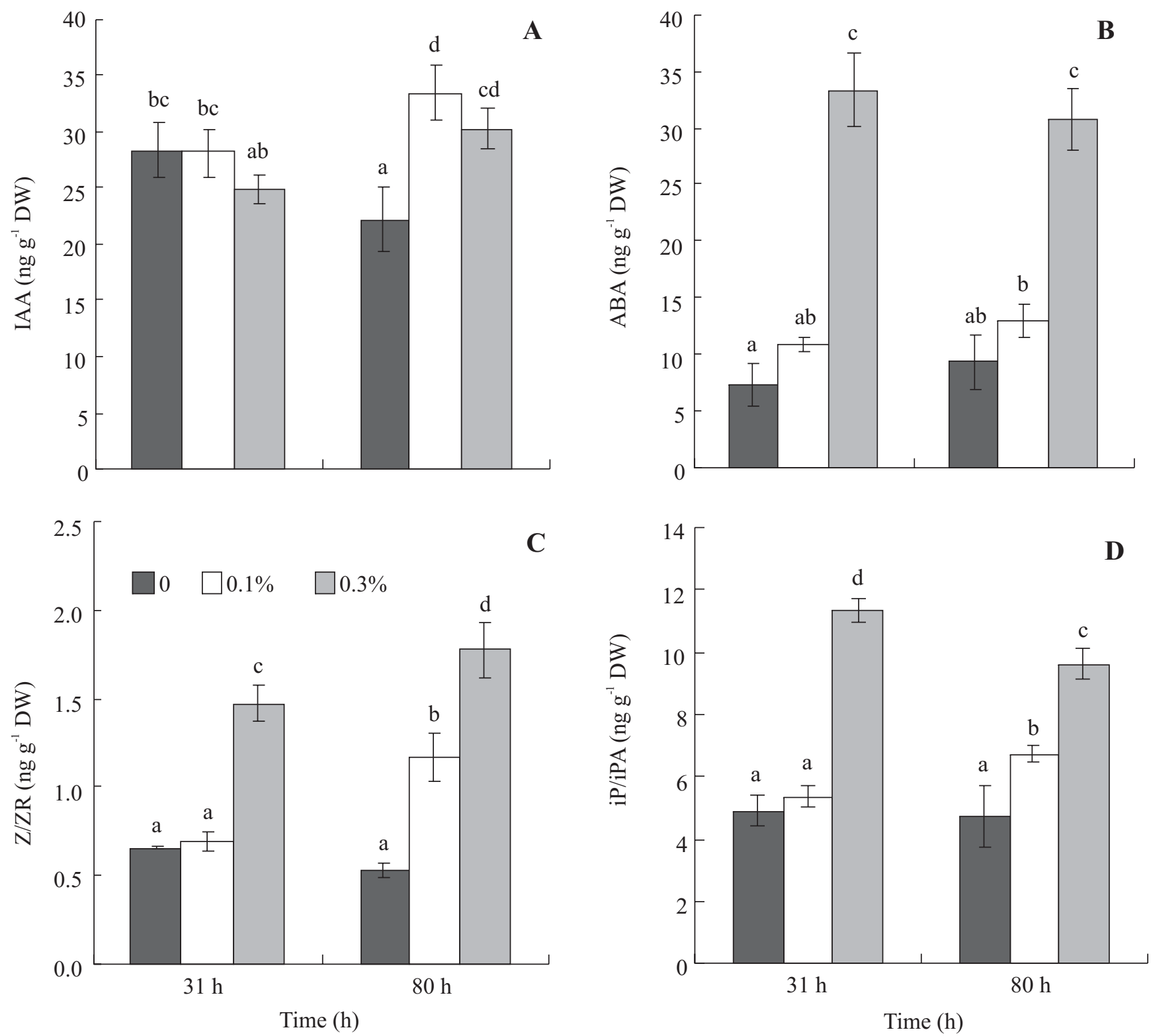

Figure 1. Endogenous levels of indole-3-acetic acid, IAA (A), abscisic acid, ABA (B), zeatin/zeatin riboside, Z/ZR (C) and $N^{6}\left(\Delta^{2}\right.$-isopentenyl) adenine/ $N^{6}\left(\Delta^{2}\right.$-isopentenyl) adenosine, iP/iPA (D) in pea seedlings 31 and $80 \mathrm{~h}$ after hydrogen cyanamide treatment $(0,0.1 \%$, and $0.3 \%)$. Significant differences within the same hormone $(P<0.05)$ are indicated with different letters. $n=3 \pm$ SD.

(Figure 1C,D). In control plants the levels of both CKs remained low without much variation in both evaluations. Mild stress, such as that caused by the highest HC concentration in pea, has been associated with stimulation of metabolic activity in plants, in an effort to overcome the adverse conditions. This increase in CK levels could be the consequence of this increased metabolic activity of stressed plants. Pospíšilová et al.
(2005) found a strong increase in endogenous levels of CKs in French bean and tobacco plants treated with 100 $\mu \mathrm{M} A B A$ and afterwards exposed to severe water stress.

The results of this study complement findings of previous investigations in which the mode of action of HC during dormancy breakage in vegetative tissues and seeds was studied (Northcott and Nowak, 1988; Pérez and Lira, 2005; Lombard et al., 2006; Jiménez et al., 2008). In addition to 
the participation of catalase and $\mathrm{H}_{2} \mathrm{O}_{2}$ and, in consequence, of ABA, we observed an increase in endogenous levels of IAA and CKs as an effect of HC application. Similar results have been observed in oil palm seeds by Jiménez et al. (2008). These results may suggest that HC or the stress reaction thereafter affect synthesis or metabolism of IAA and CKs in plants. However, the reason and function for these events needs to be investigated.

Acknowledgments: The authors would like to thank the German Academic Exchange Service (DAAD) for financial support in the form of short-time fellowships to EG and $\mathrm{JH}$ and a long-term scholarship to VMJ. Authors also wish to thank anonymous reviewers for helpful comments.

\section{REFERENCES}

Alizaga R, Guevara E, Herrera J (1992) Efecto de algunos tratamientos químicos sobre el período de reposo del maní (Arachis hypogea). Agron. Costarric. 16:29-36.

Apel K, Hirt H (2004) Reactive oxygen species: metabolism, oxidative stress and signal transduction. Annu. Rev. Plant Biol. 55:373-399.

Cañizares A, Rojas E (2001) Efecto de la cianamida de hidrógeno y el ácido 2-cloroetilfosfónico sobre la foliación, floración y fructificación de la lima "Tahiti”. Bioagro 13:10-14.

Demason DA, Chawla R (2006) Auxin/gibberellin interactions in pea leaf morphogenesis. Bot. J. Linn. Soc. 250:45-59.

Grossmann K (2007) Auxin herbicide action: lifting the veil step by step. Plant Signal Behav. 2:420-422.

Guevara E, Herrera J (1989) Efecto de la cianamida hidrogenada sobre el reposo de tubérculos de papa (Solanum tuberosum L.) cv. Atzimba. Agron. Costarric. 13:83-92.

Havlová M, Dobrev PI, Motyka V, Štorchová H, Libus J, Dobrá J, Malbeck J, Gaudinová A, Vanková R (2008) The role of cytokinins in responses to water deficit in tobacco plants over-expressing trans-zeatin Oglucosyltransferase gene under $35 S$ or SAG12 promoters. Plant Cell Environ. 31:341-353.

Herrera J, Alizaga R, Guevara E (1998) Use of chemical treatments to induce seed germination in oil palm (Elaeis guineensis). ASD Oil Palm Papers 18:1-16.

Jiménez VM, Guevara E, Herrera J, Bangerth F (2005)
Evolution of endogenous hormone concentration in embryogenic cultures of carrot during early expression of somatic embryogenesis. Plant Cell Rep. 23:567-572.

Jiménez VM, Guevara E, Herrera J, Alizaga R, Bangerth F (2008) Changes in hormone concentration during dormancy release of oil palm (Elaeis guineensis) seeds. Seed Sci. Technol. in press.

Lombard PJ, Cook NC, Bellstedt DU (2006) Endogenous cytokinin levels of table grape vines during spring budburst as influenced by hydrogen cyanamide application and pruning. Sci. Hort. 109:92-96.

Mahhou A, Alahoui H, Jadari R (2003) Effets de la cyanamide hydrogène et de l'acide gibbérellique sur la levée de dormance du pommier 'Dorsett Golden’ au sud du Maroc. Fruits 58:229-238.

Netting AG (2000) pH, abscisic acid and the integration of metabolism in plants under stressed and non-stressed conditions: cellular responses to stress and their implication for plant water relations. J. Exp. Bot. 51:147-158.

Northcott D, Nowak J (1988) Effects of hydrogen cyanamide on seed potato. Potato Res. 31:95-103.

Pérez FJ, Lira W (2005) Possible role of catalase in postdormancy bud break in grapevines. J. Plant Physiol. 162:301-308.

Pospíšilová J, Vágner M, Malbeck J, Trávnícková A, Batková P (2005) Interactions between abscisic acid and cytokinins during water stress and subsequent rehydration. Biol. Plant. 49:533-540.

Quijada O, Araujo F, Corzo P (1999) Efecto de la poda y la cianamida hidrogenada sobre la brotación, fructificación, producción y calidad de frutos del guayabo (Psidium guajava L.) en el municipio Mara del Estado Zulia. Rev. Fac. Agron. (LUZ) 16:276-290.

Quirino BF, Normanly J, Amasino RM (1999) Diverse range of gene activity during Arabidopsis thaliana leaf senescence includes pathogen-independent induction of defense-related genes. Plant Mol. Biol. 40:267-278.

Thimmaraju R, Bhagyalakshmi N, Narayan MS, Ravishankar GA (2003) Food-grade chemical and biological agents permeabilize red beet hairy roots, assisting the release of betalaines. Biotechnol. Prog. 19:1274-1282.

Wang G, Römheld V, Li C, Bangerth F (2006) Involvement of auxin and CKs in boron deficiency induced changes in apical dominance of pea plants (Pisum sativum L.). J. Plant Physiol. 163:591-600. 